\title{
Octahedral and Tetrahedral Cobalt(II) Sites in Cobalt Chloride Complexes with Polyethers ${ }^{\dagger}$
}

\author{
Saša Petriček \\ University of Ljubljana, Faculty of Chemistry and Chemical Technology, \\ Aškarčeva c. 5, SI-1000 Ljubljana, Slovenia \\ (E-mail: sasa.petricek@fkkt.uni-lj.si)
}

RECEIVED AUGUST 16, 2010; REVISED MAY 2, 2011; ACCEPTED JUNE 27, 2011

\begin{abstract}
A reaction of cobalt chloride hexahydrate with dimethoxyethane (dme) resulted in a dinuclear complex $\left[\mathrm{CoCl}_{2}(\mathrm{dme})\right]_{2}(\mathbf{1})$. The complex 1 reacted with di(2-methoxyethyl) ether (diglyme) in tetrahydrofuran (thf) solvent achieving polymeric $\left[\mathrm{Co}_{2} \mathrm{Cl}_{4}(\text { diglyme })\right]_{n}$ (2). A reaction of cobalt chloride hexahydrate, diglyme and $\left(\mathrm{CH}_{3}\right)_{3} \mathrm{SiCl}$ in thf yielded the crystals of $\left[\mathrm{Co}_{2} \mathrm{Cl}_{4}(\right.$ diglyme $)($ thf $\left.)\right](3)$. Both, tetrahedral and octahedral environments of cobalt ions were found in each of the complexes, $\mathbf{1}, \mathbf{2}$ and $\mathbf{3}$. Cobalt ions display a distorted octahedral geometry with bridging chlorides and terminal oxygen atoms from ether ligands and a distorted tetrahedral geometry with non-bridging and bridging chlorides. A four- and a sixcoordinate cobalt ion are linked by a double chloride bridge in the dinuclear complexes $\mathbf{1}$ and $\mathbf{3}$. Two tetrahedral or two octahedral cobalt ions in $\mathbf{2}$ are connected by double chloride bridges in dinuclear units which are linked to infinite chains by single chloride bridges. (doi: 10.5562/cca1747)
\end{abstract}

Keywords: dinuclear, polymeric cobalt chloride complexes, dimethoxyethane, di(2-methoxyethyl), crystal structure, bridging chlorides

\section{INTRODUCTION}

Polyethers, dme and diglyme, are O-donor ligands able to coordinate in a chelate mode to a whole range of metals; complexes of lanthanide halides have been extensively studied. ${ }^{1-9}$ On the other hand, few examples of corresponding first row transition metal complexes were prepared. The structurally characterized complexes of transition metals (III) and (IV) are mononuclear molecular $\left[\mathrm{MCl}_{3}(\right.$ diglyme $\left.)\right](\mathrm{M}=\mathrm{Sc}, \mathrm{Ti}),{ }^{10,11}\left[\mathrm{TiCl}_{4}(\mathrm{dme})\right]^{12}$ or ionic complexes $\left[\mathrm{FeCl}_{2}(\mathrm{dme})_{2}\right]\left[\mathrm{FeCl}_{4}\right]$. ${ }^{13}$ Lately, we reported polymeric, dinuclear and mononuclear dme and diglyme complexes of manganese(II), nickel(II) and zinc(II) chlorides. ${ }^{14}$ The complexes of zinc and manganese reveal a lower nuclearity of diglyme complexes, $\left[\mathrm{ZnCl}_{2}\right.$ (diglyme) $],\left[\mathrm{MnCl}_{2} \text { (diglyme) }\right]_{2}$, in comparison to dme complexes, $\left[\mathrm{ZnCl}_{2}(\mathrm{dme})\right]_{2},\left[\mathrm{MnCl}_{2}(\mathrm{dme})\right]_{n}{ }^{14}$

A propensity of $\mathrm{Zn}^{2+}$ and $\mathrm{Co}^{2+}$ to form four- and six-coordinate complexes ${ }^{15}$ and their similar ionic radii (coordination number six: $\mathrm{Zn}^{2+} 0.745 \AA$ and $\mathrm{Co}^{2+} 0.740$ $\AA)^{16}$ can result in similar molecular structures of $\mathrm{ZnCl}_{2}$ and $\mathrm{CoCl}_{2}$ complexes with some O-donor ligands. ${ }^{17-21}$ We prepared cobalt chloride complexes with dme and diglyme to compare their synthesis conditions and structure to those of zinc chloride complexes with the same polyether ligands ${ }^{14}$ and to elucidate influence of the ligands dme and diglyme to the nuclearity of cobalt chloride complexes.

\section{EXPERIMENTAL}

\section{General}

All the manipulations were carried out under an inert atmosphere, with the exception of the first step in the preparation of the complex 1 .

Cobalt chloride hexahydrate (Aldrich, $99.99 \%$ ), diglyme (Fluka, 99.5\%) and chlorotrimethylsilane (Aldrich, $97.0 \%$ ) were used as delivered. Solvents were dried $\left(\mathrm{CH}_{2} \mathrm{Cl}_{2}\right.$ over calcium hydride, thf over $\left.\mathrm{Na} / \mathrm{K}\right)$ and distilled before use.

Suspensions of ground samples in nujol were prepared in a dry box. IR spectra were recorded on a Perkin Elmer Spectrum 100 FT-IR spectrometer from $\tilde{v}_{\max }=400$ to $4000 \mathrm{~cm}^{-1}$.

Chlorine contents were determined by potentiometric titrations of chloride ions with silver nitrate. Elemental analyses were carried out on a Perkin-Elmer 2400 Series II CHN analyzer at the University of Ljubljana (Department of Organic Chemistry).

\footnotetext{
$\dagger$ Presented as a plenary lecture at the $18^{\text {th }}$ Croatian-Slovenian Crystallographic Meeting held in Varaždin, Croatia, June 17-21, 2009.
} 
Powdered samples were sealed into tubes in a dry box and room temperature magnetic susceptibility measurements were performed by a Sherwood Scientific MBS-1 balance using $\mathrm{Hg}\left[\mathrm{Co}(\mathrm{NCS})_{4}\right]$ as a standard. Diamagnetic corrections were applied using Pascal's constants and the magnetic moments were calculated. ${ }^{22}$

\section{Synthesis of $\left[\mathrm{CoCl}_{2}(\mathrm{dme})\right]_{2}$ (1)}

Solvent (dme, $30 \mathrm{~mL}$ ) was added to $\mathrm{CoCl}_{2} \times 6 \mathrm{H}_{2} \mathrm{O}(1.07 \mathrm{~g}$, $4.50 \mathrm{mmol}$ ). A suspension was stirred for one hour in an open Schlenk flask at $70{ }^{\circ} \mathrm{C}$ followed by stirring at room temperature in an inert atmosphere for two days. Approximately one half of the solution above the precipitate was filtered off and crystals of $\mathbf{1}$ grew out of the solution during slow evaporation at reduced pressure at room temperature. The remaining suspension was dried in vacuo, the complex 1 (0.945 g, $95.5 \%$ yield) was gained. Anal. Calcd. mass fractions of elements, $w / \%$, for $\mathrm{C}_{8} \mathrm{H}_{20} \mathrm{Cl}_{4} \mathrm{Co}_{2} \mathrm{O}_{4}\left(M_{\mathrm{r}}=\right.$ 439.90) are: $\mathrm{C}, 21.84 ; \mathrm{H}, 4.58 ; \mathrm{Cl}, 32.24$; found: $\mathrm{C}, 21.98$; $\mathrm{H}, 4.65 ; \mathrm{Cl}, 32.02$. IR ( 1 in nujol) $\tilde{v}_{\max } / \mathrm{cm}^{-1}: 1260 \mathrm{~m}$, 1092 s, 1047 vs, 1017 vs, 871 w, $861 \mathrm{~m}, 799$ s, 669 w, $465 \mathrm{w}, 451 \mathrm{w}$. Magnetic moment of 1: $\mu, 4.64 \mathrm{BM}$.

\section{Synthesis of $\left[\mathrm{Co}_{2} \mathrm{Cl}_{4}(\text { diglyme })\right]_{n}$ (2)}

Solvent (thf, $30 \mathrm{~mL}$ ) and ligand (diglyme, $0.554 \mathrm{~g}, 4.13$ mmol) were added to $\left[\mathrm{CoCl}_{2}(\mathrm{dme})\right]_{2}(0.756 \mathrm{~g}, 1.72$ $\mathrm{mmol}$ ). A suspension was stirred for two days at room temperature and then dried in vacuo, the complex 2 (0.640 g, $94.5 \%$ yield) was gained. Anal. Calcd. mass fractions of elements, $w / \%$, for $\mathrm{C}_{6} \mathrm{H}_{14} \mathrm{Cl}_{4} \mathrm{Co}_{2} \mathrm{O}_{3}\left(M_{\mathrm{r}}=\right.$ 393.83) are: $\mathrm{C}, 18.30 ; \mathrm{H}, 3.58 ; \mathrm{Cl}, 36.01$; found: $\mathrm{C}$, 18.50; H, 3.70; Cl, 35.84. IR ( 2 in nujol) $\tilde{v}_{\max } / \mathrm{cm}^{-1}: 1260 \mathrm{~s}$, $1153 \mathrm{w}, 1081 \mathrm{~s}, 1044 \mathrm{~s}, 1018 \mathrm{~s}, 950 \mathrm{~m}, 865 \mathrm{~m}, 800 \mathrm{~s}$, $556 \mathrm{w}, 465 \mathrm{w}, 452$ w. Recrystallization from dichloromethane resulted in crystals of the polymeric complex 2. Magnetic moment of 2: $\mu, 4.61 \mathrm{BM}$.

\section{Synthesis of $\left[\mathrm{Co}_{2} \mathrm{Cl}_{4}(\right.$ diglyme $)($ thf $\left.)\right]$ (3)}

Solvent (thf, $30 \mathrm{~mL}$ ), ligand (diglyme, $1.041 \mathrm{~g}, 7.76$ $\mathrm{mmol})$ and $\left(\mathrm{CH}_{3}\right)_{3} \mathrm{SiCl}(15.226 \mathrm{~g}, 140 \mathrm{mmol})$ were added to $\mathrm{CoCl}_{2} \cdot 6 \mathrm{H}_{2} \mathrm{O}(1.372 \mathrm{~g}, 5.77 \mathrm{mmol})$. A suspension was stirred for a day at room temperature. Approximately one half of the solution above the precipitate was filtered off and crystals of $\mathbf{3}$ grew out of the solution during slow evaporation at reduced pressure. The remaining suspension was dried in vacuo and recrystallization of the powder product from $\mathrm{CH}_{2} \mathrm{Cl}_{2}$ resulted in the crystals of the complex 2 . IR of the dried product in Nujol is similar to the IR spectrum of the complex 2 .

\section{Crystal Structure Determination}

Details of the crystal data collections and the refinement parameters of the complexes $\mathbf{1} \mathbf{- 3}$ are listed in Table 1 .
All studied compounds are hygroscopic. The crystals were greased on a glass thread. Diffraction data were collected on a Nonius Kappa diffractometer with a CCD area detector at 150(2) K. Graphite monochromatic Mo-K $\alpha$ radiation $(\lambda=0.71073 \AA)$ was employed for all measurements. The data were processed using the program DENZO. ${ }^{23}$ The crystal structures were solved by direct methods implemented in SHELXS-97 and refined by a full-matrix least-squares procedure based on $F^{2}$ (SHELXL-97). ${ }^{24,25}$ All non-hydrogen atoms were refined anisotropically. All hydrogen atoms were included in the models at geometrically calculated positions and refined using a riding model. Figures depicting the structures were prepared by DIAMOND ${ }^{26}$ and ORTEP $3 .^{27}$

\section{RESULTS AND DISCUSSION}

\section{Syntheses}

A reaction of cobalt chloride hexahydrate and dme at $70{ }^{\circ} \mathrm{C}$ achieved the water-free complex $1 .^{28}$ Similar complexes of lanthanide and manganese chloride could be prepared only by reactions of metal chloride hydrates and dme in the presence of an excess amount of chlorotrimethylsilane, which guarantees a complete consumption of water. ${ }^{1,14}$ The complex of cobalt chloride with diglyme, 2, was prepared from the complex $\mathbf{1}$ and diglyme in the solvent thf. Crystals of the dinuclear complex 3 grew out of a solution obtained by a reaction of metal chloride hexahydrate, diglyme and chlorotrimethylsilane in thf, similarly to the syntheses and crystallizations of $\left[\operatorname{LnX}_{3}\right.$ (diglyme)(thf).$^{3-5}$

\section{Magnetic Measurements}

The magnetic moments of cobalt complexes 1 (4.64 $\mathrm{BM})$ and 2 (4.61 BM) measured at room temperature suggest a high spin $d^{7}$ configuration of tetrahedrally and octahedrally coordinated $\mathrm{Co}^{2+}$ ions. ${ }^{22}$

\section{Crystal Structure of the Polymeric Complex 1, 2 and 3}

The molecules of the complexes $\mathbf{1},\left[\mathrm{CoCl}_{2}(\mathrm{dme})\right]_{2}$, and 3 , $\left[\mathrm{Co}_{2} \mathrm{Cl}_{4}\right.$ (diglyme)(thf)], are built of a four- and a sixcoordinate cobalt ion connected by two bridging chlorides into a dinuclear molecule (Figure 1). $\mathrm{Co} 2$ ion is tetrahedrally coordinated by two bridging and two nonbridging chlorides and $\mathrm{Col}$ ion displays a distorted octahedral geometry with two bridging chlorides in cis positions and four oxygen atoms in both complexes $\mathbf{1}$ and 3. In 1 are four oxygen donor atoms from two dme molecules (Figure 1a) and in 3, three oxygen donor atoms come from one diglyme molecule and one from a thf molecule (Figure 1b). The thf molecule coordinated in the complex $\mathbf{3}$ is in a disorder, four atoms are in a 
Table 1. Crystallographic data, data collection and structure refinement data for the compounds $\left[\mathrm{CoCl}_{2}\left(\mathrm{dme}_{2}\right)\right]_{2}(\mathbf{1}),\left[\mathrm{Co}_{2} \mathrm{Cl}_{4}(\mathrm{di}-\right.$ glyme $]_{n}(\mathbf{2}),\left[\mathrm{Co}_{2} \mathrm{Cl}_{4}\right.$ (diglyme)(thf)] (3)

\begin{tabular}{|c|c|c|c|}
\hline & 1 & 2 & 3 \\
\hline Chemical formula & {$\left[\mathrm{CoCl}_{2}\left(\mathrm{O}_{2} \mathrm{C}_{4} \mathrm{H}_{10}\right)\right]_{2}$} & {$\left[\mathrm{Co}_{2} \mathrm{Cl}_{4}\left(\mathrm{O}_{3} \mathrm{C}_{6} \mathrm{H}_{14}\right)\right]_{n}$} & {$\left[\mathrm{Co}_{2} \mathrm{Cl}_{4}\left(\mathrm{O}_{4} \mathrm{C}_{10} \mathrm{H}_{22}\right)\right]$} \\
\hline Colour & blue & blue & blue \\
\hline$M / \mathrm{g} \mathrm{mol}^{-1}$ & 439.90 & 393.83 & 465.94 \\
\hline Crystal system & monoclinic & monoclinic & monoclinic \\
\hline Space group & $C 2 / c($ no. 15$)$ & $C 2 / m($ no. 12$)$ & $P 2_{1} / m$ (no. 14$)$ \\
\hline$a / \AA$ & $13.6498(4)$ & $10.1578(3)$ & $8.4417(3)$ \\
\hline$b / \AA$ & $10.0008(3)$ & $11.5215(4)$ & $11.3689(4)$ \\
\hline$c / \AA$ & $12.8786(4)$ & $12.4400(5)$ & $9.6486(3)$ \\
\hline$\beta /^{\mathrm{o}}$ & $100.902(2)$ & $110.025(2)$ & $107.931(2)$ \\
\hline$V / \AA^{3}$ & $1726.29(9)$ & $1367.87(99$ & $881.03(5)$ \\
\hline$Z$ (formula units per cell) & 4 & 4 & 2 \\
\hline$D_{\text {cal. }} /\left(\mathrm{g} \mathrm{cm}^{-3}\right)$ & 1.693 & 1.912 & 1.756 \\
\hline$\mu / \mathrm{mm}^{-1}$ & 2.541 & 3.190 & 2.495 \\
\hline Crystal size / mm & $0.1 \times 0.08 \times 0.08$ & $0.15 \times 0.14 \times 0.13$ & $0.08 \times 0.06 \times 0.06$ \\
\hline$\theta$ Range $/^{\circ}$ & $3.16-27.48$ & $3.49-27.43$ & $4.22-27.45$ \\
\hline Total number of collected reflections & 3646 & 2993 & 3807 \\
\hline Number of unique reflections & 1969 & 1610 & 2091 \\
\hline$R_{\text {int }}$ & 0.019 & 0.016 & 0.027 \\
\hline Number of reflections used & 1730 & 1465 & 1651 \\
\hline Threshold & {$[I>2.0 \sigma(I)]$} & {$[I>2.0 \sigma(I)]$} & {$[I>2.0 \sigma(I)]$} \\
\hline Number of parameters & 85 & 79 & 110 \\
\hline$R^{(\mathrm{a})}$ (observed) & 0.022 & 0.036 & 0.034 \\
\hline$w R_{2}^{(\mathrm{b})}$ & 0.051 & 0.099 & 0.064 \\
\hline$S$ & 1.016 & 1.102 & 1.064 \\
\hline Max/min residual electron density / e $\AA^{-3}$ & $0.282 /-0.363$ & $0.716 /-1.45$ & $0.418 /-0.419$ \\
\hline
\end{tabular}

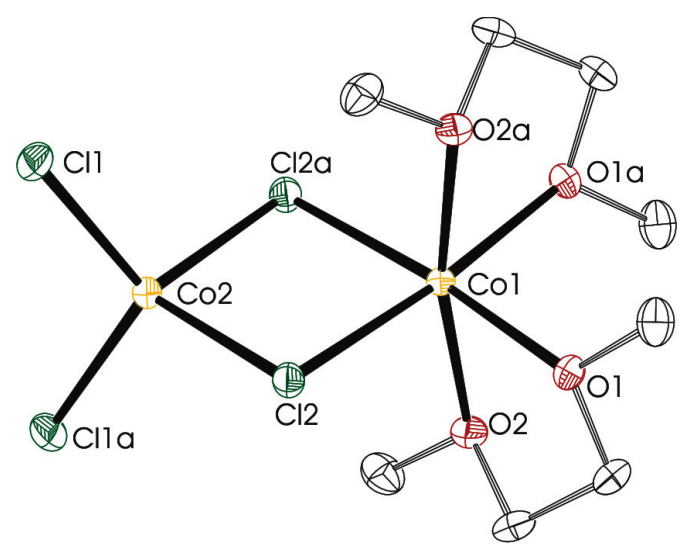

(a)

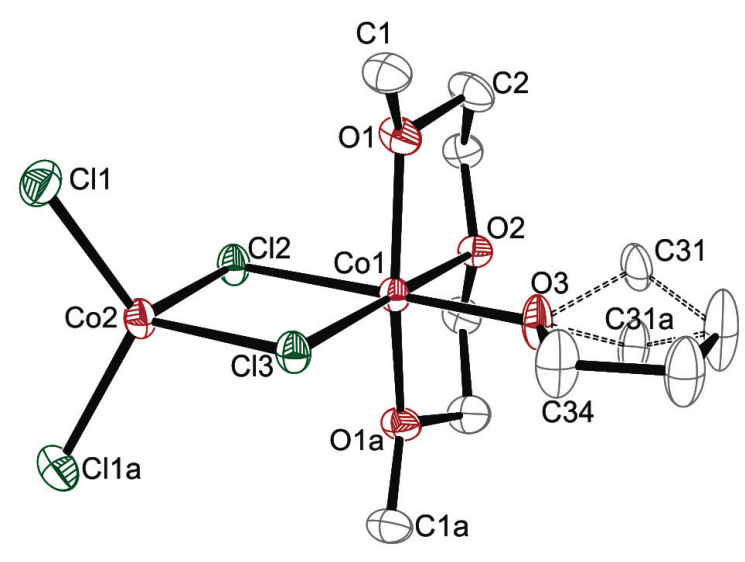

(b)

Figure 1. Six- and four-coordinate cobalt ions in the binuclear molecular compounds, $\left[\mathrm{CoCl}_{2}\left(\mathrm{dme}_{2}\right]_{2}(\mathbf{1}),(\mathrm{a})\right.$; $\left[\mathrm{Co}_{2} \mathrm{Cl}_{4}(\mathrm{diglyme})\right.$ (thf)] (3), (b). The molecule of thf is disordered. Hydrogen atoms are omitted for clarity. 
mirror plane, but C31 is located at two symmetry dependent positions.

Selected interatomic distances and angles of the complexes $\mathbf{1}$ and $\mathbf{3}$ are listed in Table 2.

The complex 1 is isostructural to $\left[\mathrm{ZnCl}_{2}(\mathrm{dme})\right]_{2}{ }^{14}$ A comparison of bridging $\mathrm{Co}-\mathrm{Cl}$ and $\mathrm{Zn}-\mathrm{Cl}(\mathrm{Zn} 1-\mathrm{Cl}$ 2.4140(4), Zn2-Cl 2.3467(4) $\AA$ ) interatomic distances shows a relative shift of bridging chlorides to the tetrahedrally coordinated $\mathrm{Co} 2$ ion in 1 and $\mathrm{Zn} 2$ in $\left[\mathrm{ZnCl}_{2}\right.$ $(\mathrm{dme})]_{2}$; metal to metal distances are almost the same

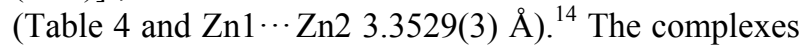
of cobalt(II) and zinc chloride exhibit coordination numbers $4 / 6$ in dinuclear dme complexes ( 1 and Ref. 14) and coordination number 4 in mononuclear tetramethylethylenediamine (tmeda) complexes. $^{29,30}$ On the contrary, the $\mathrm{MnCl}_{2}$ complexes exhibit coordination number six with dme and tmeda ligands, resulting in polymeric complexes. ${ }^{14,30}$ These results confirm that tetrahedral complexes are more readily formed with $\mathrm{Co}^{2+}$ than with cations of other d-block elements except zinc.

Octahedral and tetrahedral cobalt ions are connected by chloride bridges into the chains of the complex 2 (Figure 2). Three bridging chlorides and three oxygen atoms from a diglyme molecule are coordinated to a cobalt ion $\mathrm{Co} 1$ in a distorted octahedral geometry, while a non-bridging and three bridging chlorides are coordinated to a cobalt ion $\mathrm{Co} 2$ in a distorted tetrahedral geometry. Two six- and two four-coordinate cobalt ions are connected by double chloride bridges into repeating dinuclear units of $\left[\mathrm{CoCl}_{2}(\text { diglyme })\right]_{2}$ and $\left[\mathrm{CoCl}_{2}\right]_{2}$, respectively. Dinuclear units are connected by single

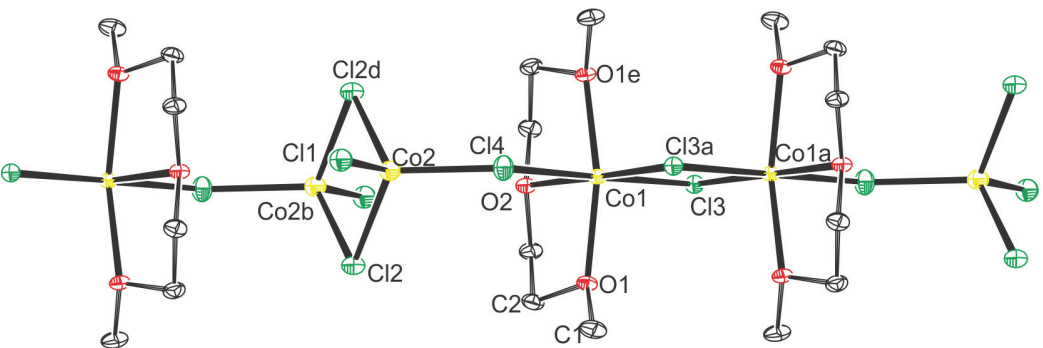

(a)

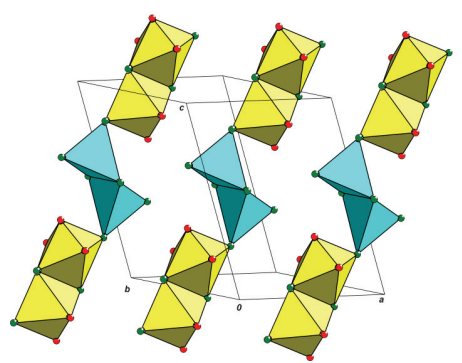

(b)

Figure 2. An infinite chain in the complex 2, $\left[\mathrm{Co}_{2} \mathrm{Cl}_{4}(\text { diglyme })\right]_{n}$ (a). Hydrogen atoms are omitted for clarity. Infinite chains of coordination polyhedra of cobalt ions in the unit cell; alternating pairs of edge-sharing octahedra and edge-sharing tetrahedra in the complex 2. A four- and a six-coordinate cobalt ion are connected by a single chloride bridge resulting in a corner sharing of a tetrahedron and an octahedron (b). Carbon and hydrogen atoms are omitted for clarity.

Table 2. Selected interatomic distances and angles in $\left[\mathrm{CoCl}_{2}(\mathrm{dme})\right]_{2}(\mathbf{1})$, and in $\left[\mathrm{Co}_{2} \mathrm{Cl}_{4}(\operatorname{diglyme})(\mathrm{thf})\right](\mathbf{3})$

\begin{tabular}{|c|c|c|c|c|c|c|c|}
\hline \multicolumn{4}{|c|}{$\left[\mathrm{CoCl}_{2}(\mathrm{dme})\right]_{2}(\mathbf{1})$} & \multicolumn{4}{|c|}{$\left[\mathrm{Co}_{2} \mathrm{Cl}_{4}(\right.$ diglyme $)($ thf $\left.)\right](3)$} \\
\hline \multicolumn{2}{|c|}{ Interatomic distance $/ \AA$} & \multicolumn{2}{|c|}{ Angle $/{ }^{\circ}$} & \multicolumn{2}{|c|}{ Interatomic distance / $\AA$} & \multicolumn{2}{|c|}{ Angle $/^{\circ}$} \\
\hline $\mathrm{Co} 1-\mathrm{Cl} 2$ & $2.4367(4)$ & $\mathrm{Cl} 2-\mathrm{Co} 1-\mathrm{Cl} 2 \mathrm{a}$ & $87.70(2)$ & $\mathrm{Co} 1-\mathrm{Cl} 2$ & $2.5097(10)$ & $\mathrm{Cl} 2-\mathrm{Co} 1-\mathrm{Cl} 3$ & $87.88(3)$ \\
\hline & & $\mathrm{Cl} 2-\mathrm{Co} 1-\mathrm{O} 1 \mathrm{a}$ & $174.25(3)$ & $\mathrm{Co} 1-\mathrm{Cl} 3$ & $2.3926(10)$ & $\mathrm{C} 12-\mathrm{Co} 1-\mathrm{O} 3$ & $179.24(8)$ \\
\hline $\mathrm{Co} 2-\mathrm{Cl} 2$ & $2.3262(4)$ & $\mathrm{Cl} 2-\mathrm{Co} 1-\mathrm{O} 2$ & $92.21(3)$ & & & $\mathrm{Cl} 3-\mathrm{Co} 1-\mathrm{O} 1$ & $101.84(5)$ \\
\hline \multirow[t]{2}{*}{$\mathrm{Co} 2-\mathrm{Cl1}$} & $2.2295(5)$ & $\mathrm{Cl} 2 \mathrm{a}-\mathrm{Co} 1-\mathrm{O} 2$ & $97.08(3)$ & $\mathrm{Co} 2-\mathrm{Cl1}$ & $2.2345(8)$ & $\mathrm{Cl} 3-\mathrm{Co} 1-\mathrm{O} 3$ & $91.36(8)$ \\
\hline & & $\mathrm{O} 1-\mathrm{Co} 1-\mathrm{O} 2$ & $77.74(5)$ & $\mathrm{Co} 2-\mathrm{Cl} 2$ & $2.3228(11)$ & $\mathrm{O} 1-\mathrm{Co} 1-\mathrm{O} 2$ & $78.27(5)$ \\
\hline Co1-O1 & $2.0948(11)$ & $\mathrm{O} 1-\mathrm{Co} 1-\mathrm{O} 2 \mathrm{a}$ & $93.30(5)$ & $\mathrm{Co} 2-\mathrm{Cl} 3$ & $2.3322(10)$ & $\mathrm{O} 1-\mathrm{Co} 1-\mathrm{O} 3$ & $94.15(6)$ \\
\hline \multirow[t]{8}{*}{$\mathrm{Co} 1-\mathrm{O} 2$} & $2.1207(11)$ & $\mathrm{O} 2-\mathrm{Co} 1-\mathrm{O} 2 \mathrm{a}$ & $167.12(7)$ & & & & \\
\hline & & $\mathrm{Cl1}-\mathrm{Co} 2-\mathrm{Cl1a}$ & $114.60(3)$ & Co1-O1 & $2.081(2)$ & $\mathrm{Cl1}-\mathrm{Co} 2-\mathrm{Cl1a}$ & $117.49(4)$ \\
\hline & & $\mathrm{Cl} 2-\mathrm{Co} 2-\mathrm{Cl} 2 \mathrm{a}$ & $93.05(2)$ & $\mathrm{Co} 1-\mathrm{O} 2$ & $2.082(3)$ & $\mathrm{Cl} 1-\mathrm{Co} 2-\mathrm{Cl} 2$ & $111.57(3)$ \\
\hline & & $\mathrm{C} 11-\mathrm{Co} 2-\mathrm{Cl} 2$ & $114.41(2)$ & $\mathrm{Co} 1-\mathrm{O} 3$ & $2.089(3)$ & $\mathrm{C} 11-\mathrm{Co} 2-\mathrm{Cl} 3$ & $109.88(3)$ \\
\hline & & & & & & $\mathrm{Cl} 2-\mathrm{Co} 2-\mathrm{Cl} 3$ & $93.94(4)$ \\
\hline & & $\mathrm{Co} 1-\mathrm{Cl} 2-\mathrm{Co} 2$ & $89.62(2)$ & & & & \\
\hline & & & & & & $\mathrm{Co} 1-\mathrm{Cl} 2-\mathrm{Co} 2$ & $87.78(3)$ \\
\hline & & & & & & $\mathrm{Co} 1-\mathrm{Cl} 3-\mathrm{Co} 2$ & $90.40(4)$ \\
\hline
\end{tabular}


chloride bridges into polynuclear chains. The repeating unit of the chain could be described as [Co(diglyme) $(\mu-\mathrm{Cl})_{2} \mathrm{Co}$ (diglyme $\left.)(\mu-\mathrm{Cl}) \mathrm{CoCl}(\mu \mathrm{Cl})_{2} \mathrm{CoCl}(\mu-\mathrm{Cl})\right]$.

Selected interatomic distances and angles of the complex 2 are listed in Table 3.

Chains incorporating chloride bridged coordination polyhedra of different types as in the complex $\mathbf{2}$ are rare, while infinite chains of chloride bridged single type polyhedra of divalent metals with donor ligands are well documented. ${ }^{31}$ An alternating tetrahedral and octahedral coordination of cobalt ions was found in chains of $\left[\mathrm{Co}_{4}(\mu-\mathrm{Cl})_{6} \mathrm{Cl}_{2}(\mathrm{thf})_{4}(\mathrm{MeOH})_{2}\right]_{n}{ }^{32}$ and $[\mathrm{Co}$ $\left.(\text { daa })_{2}(\mu-\mathrm{Cl})_{2} \mathrm{CoCl}_{2}\right]_{n} \quad($ daa $=$ 4-hydroxy-4-methyl-2pentanon). ${ }^{21}$ Tetrahedral $\mathrm{Co}$ (II) sites are coordinated only by chlorides, while O-donor ligands and bridging chlorides are coordinated to octahedral $\mathrm{Co}$ (II) sites in the complexes 2, $\left[\mathrm{Co}_{4}(\mu-\mathrm{Cl})_{6} \mathrm{Cl}_{2}(\text { thf })_{4}(\mathrm{MeOH})_{2}\right]_{n}{ }^{32}$ and $[\mathrm{Co}$ (daa) $\left.)_{2}(\mu-\mathrm{Cl})_{2} \mathrm{CoCl}_{2}\right]_{n}{ }^{21}$ Cobalt ions are connected to infinite chains by double and single chloride bridges in the complexes 2 and $\left[\mathrm{Co}_{4}(\mu-\mathrm{Cl})_{6} \mathrm{Cl}_{2}(\text { thf })_{4}(\mathrm{MeOH})_{2}\right]_{n},{ }^{32}$ but only single chloride bridges link cobalt ions in $\left[\mathrm{Co}(\mathrm{daa})_{2}(\mu-\mathrm{Cl})_{2} \mathrm{CoCl}_{2}\right]_{n}{ }^{21}$

Co1-O interatomic distances in 1, 2 and $\mathbf{3}$ (Tables 2 and 3) are in the same range as in $\left[\mathrm{Co}(\mathrm{daa})_{2}\right.$ $\left.(\mu-\mathrm{Cl})_{2} \mathrm{CoCl}_{2}\right]_{n},{ }^{21}$ but longer than in $\left[\mathrm{Co}_{4}(\mu-\mathrm{Cl})_{6} \mathrm{Cl}_{2}\right.$ $\left.(\text { thf })_{4}(\mathrm{MeOH})_{2}\right]_{n}^{32}(2.038(2)-2.070(2) \AA)$. Interatomic distances between a four-coordinate cobalt ion $\mathrm{Co} 2$ and a non-bridging chloride $\mathrm{Cll}$ are shorter in 1, 2 and 3 than in $\left[\mathrm{Co}(\mathrm{daa})_{2}(\mu-\mathrm{Cl})_{2} \mathrm{CoCl}_{2}\right]_{\mathrm{n}}(2.2533(8) \AA)^{21}$ and $\left[\mathrm{Co}_{4}(\mu-\mathrm{Cl})_{6} \mathrm{Cl}_{2}(\text { thf })_{4}(\mathrm{MeOH})_{2}\right]_{\mathrm{n}}(2.251(3) \AA) .{ }^{32}$ The interatomic $\mathrm{Co}-\mathrm{Cl}$ (bridging) distances in the polymeric complex 2 are in a wide range from 2.266(1) to 2.500(1) $\AA$ (Table 3) due to connections of different polyhedra by single and double chloride bridges. A similar variety of interatomic $\mathrm{Co}-\mathrm{Cl}$ (bridging) distances was found in polymeric complexes $\left[\mathrm{Co}_{4}(\mu-\mathrm{Cl})_{6} \mathrm{Cl}_{2}(\text { thf })_{4}(\mathrm{MeOH})_{2}\right]_{n}$ $(2.2861(7)-2.5488(7) \AA)^{32}$ and $\left[\mathrm{Co}(\mathrm{daa})_{2}(\mu-\mathrm{Cl})_{2} \mathrm{CoCl}_{2}\right]_{n}$ $(2.295(2)-2.455(2) \AA){ }^{21}$ The average $\mathrm{Co}-\mathrm{Cl}$ (bridging) distances in the dinuclear complexes $\mathbf{1}$ and $\mathbf{3}$ are in the same range; approximately $2.32 \AA$ to tetrahedral $\mathrm{Co} 2$ and $2.44 \AA$ to octahedral Col. The distances of the two bridging chlorides to the $\mathrm{Col}$ are the same in 1 , but deviate from the average in $\mathbf{3}$ with one short $(2.3926(10)$ $\AA, \mathrm{Cl} 3$ trans to $\mathrm{O}$ (diglyme)) and one long distance (2.5097(10) $\AA, \mathrm{Cl} 2$ trans to O(thf)).

A comparison of distances between cobalt ions in the dinuclear complexes $\mathbf{1 , 3}$ and the polymeric complex 2 is shown in table 4 .

A metal to metal distance is shorter between two neighbouring cobalt ions linked by a double chloride bridge than by a single chloride bridge. Distances between two cobalt ions linked by a double chloride bridge increase from 3.1239(10) $\AA$ between two fourcoordinated $\mathrm{Co} 2$ (2) to approximately $3.35 \AA$ between a
Table 3. Selected interatomic distances and angles in $\left[\mathrm{Co}_{2} \mathrm{Cl}_{4} \text { (diglyme) }\right]_{\mathrm{n}}, 2$

\begin{tabular}{|c|c|c|c|}
\hline \multicolumn{2}{|c|}{ Interatomic distance / $\AA$} & \multicolumn{2}{|c|}{ Angles $/^{\circ}$} \\
\hline $\mathrm{Co} 1-\mathrm{Cl} 3 \mathrm{a}$ & $2.353(1)$ & $\mathrm{Cl} 3-\mathrm{Co} 1-\mathrm{Cl} 3 \mathrm{a}$ & $88.63(4)$ \\
\hline $\mathrm{Co} 1-\mathrm{Cl} 3$ & $2.449(1)$ & $\mathrm{O} 1-\mathrm{Co} 1-\mathrm{O} 2$ & $77.96(6)$ \\
\hline $\mathrm{Co} 1-\mathrm{Cl} 4$ & $2.500(1)$ & $\mathrm{O} 1-\mathrm{Co} 1-\mathrm{O} 1 \mathrm{e}$ & $155.19(13)$ \\
\hline $\mathrm{Co} 2-\mathrm{Cl1}$ & $2.208(1)$ & $\mathrm{Cl} 3-\mathrm{Co} 1-\mathrm{O} 2$ & $93.82(9)$ \\
\hline $\mathrm{Co} 2-\mathrm{Cl} 2$ & $2.326(1)$ & $\mathrm{Cl} 3 \mathrm{a}-\mathrm{Co} 1-\mathrm{O} 2$ & $177.55(9)$ \\
\hline \multirow[t]{2}{*}{$\mathrm{Co} 2-\mathrm{Cl} 4$} & $2.266(1)$ & $\mathrm{Cl} 4-\mathrm{Co} 1-\mathrm{O} 1$ & $92.92(6)$ \\
\hline & & $\mathrm{Cl1}-\mathrm{Co} 2-\mathrm{Cl} 4$ & $107.25(5)$ \\
\hline Co1-O1 & $2.122(2)$ & $\mathrm{Cl} 1-\mathrm{Co} 2-\mathrm{C} 2$ & $113.18(3)$ \\
\hline \multirow[t]{5}{*}{$\mathrm{Co} 1-\mathrm{O} 2$} & $2.097(3)$ & $\mathrm{Cl} 2-\mathrm{Co} 2-\mathrm{Cl} 4$ & $113.75(3)$ \\
\hline & & $\mathrm{Cl} 2-\mathrm{Co} 2-\mathrm{Cl} 2 \mathrm{~d}$ & $95.65(5)$ \\
\hline & & $\mathrm{Co} 2-\mathrm{Cl} 2-\mathrm{Co} 2 \mathrm{~b}$ & $84.35(5)$ \\
\hline & & $\mathrm{Co} 1-\mathrm{Cl} 3-\mathrm{Co} 1 \mathrm{a}$ & $91.37(4)$ \\
\hline & & $\mathrm{Co} 1-\mathrm{C} 14-\mathrm{Co} 2$ & $129.17(6)$ \\
\hline
\end{tabular}

Table 4. Distances between cobalt ions (octahedral Co1, tetrahedral $\mathrm{Co} 2$ ) in the complexes $\mathbf{1 , 2}$ and $\mathbf{3}$

\begin{tabular}{llll}
\hline & $\mathbf{1}$ & \multicolumn{1}{c}{$\mathbf{2}$} & \multicolumn{1}{c}{$\mathbf{3}$} \\
\hline $\mathrm{Co} 1 \cdots \mathrm{Co} 2$ & $3.3577(4)$ & $4.3062(10)$ & $3.3529(7)$ \\
$\mathrm{Co} 1 \cdots \mathrm{Co} 1 \mathrm{a}$ & & $3.4360(9)$ & \\
$\mathrm{Co} 2 \cdots \mathrm{Co} 2 \mathrm{~b}$ & & $3.1239(10)$ & \\
\hline
\end{tabular}

four- and a six-coordinated $\mathrm{Co} 2, \operatorname{Co} 1(\mathbf{1}, \mathbf{3})$ and to 3.4360(9) A between two six-coordinated Col (2). A similar distance between two six-coordinated cobalt ions was found in the complex $\left[\mathrm{Co}_{2} \mathrm{Cl}_{2}(\mathrm{meg})_{4}\right] \mathrm{Cl}_{2}$ (megethane-(1,2)-diol; $(3.470(1) \AA) .{ }^{33}$ Single chloride bridges connecting four- and six-coordinate cobalt ions resulted in significantly longer metal to metal distances in the complexes 2 (Table 4, Co1 $\cdots \mathrm{Co} 2),\left[\mathrm{Co}(\mathrm{daa})_{2}\right.$ $\left.(\mu-\mathrm{Cl})_{2} \mathrm{CoCl}_{2}\right]_{\mathrm{n}}(3.949(2), 3.967(2) \AA)^{21}$ and $\left[\mathrm{Co}_{4}(\mu-\right.$ $\left.\mathrm{Cl})_{6} \mathrm{Cl}_{2}(\mathrm{thf})_{4}(\mathrm{MeOH})_{2}\right]_{\mathrm{n}}(4.143(3) \AA) .{ }^{32}$

\section{CONCLUSIONS}

The cobalt chloride complex with dme, $\mathbf{1}$, is isostructural to the zinc chloride complex with dme. The structures of the diglyme complexes of cobalt chloride, $\mathbf{2}$, and zinc chloride differ significantly. ${ }^{14}$ The cobalt chloride complex with diglyme, $\mathbf{2}$, has a chain structure with an alternating tetrahedral and octahedral coordination of cobalt ions, while a propensity of zinc for the coordination number five ${ }^{34}$ favours isolation of the mononuclear complex $\left[\mathrm{ZnCl}_{2} \text { (diglyme) }\right]^{14}$

Nuclearity of cobalt chloride complexes with dme, $\mathbf{1}$, and diglyme, $\mathbf{2}$, is on contrary to nuclearity of manganese and zinc chloride complexes with the same 
polyether ligands. A substitution of a bidentate ligand dme in the dinuclear complex 1 with a tridentate ligand diglyme resulted in increased nuclearity of polymeric co- balt complex $\mathbf{2}$. On the contrary the zinc and manganese complexes reveal a higher nuclearity of dme complexes, $\left[\mathrm{ZnCl}_{2}(\mathrm{dme})\right]_{2}, \quad\left[\mathrm{MnCl}_{2}(\mathrm{dme})\right]_{n}$, in comparison to diglyme complexes, $\left[\mathrm{ZnCl}_{2}\right.$ (diglyme) $]$, $[\mathrm{Mn}$ $\mathrm{Cl}_{2}$ (diglyme) $]_{2}$. ${ }^{14}$

Supplementary Materials. - Crystallographic data for the structures 1 (CCDC 780566), 2 (CCDC 780567) and 3 (CCDC 780568) have been deposited with the Cambridge Crystallographic Data Centre. Copies of the data can be obtained free of charge via http://www.ccdc.cam.ac.uk/conts/retrieving.html or from CCDC, 12 Union Road, Cambridge CB2 1EZ, UK; Fax: (+44) 1223 336033; or e-mail deposit@ccdc.cam.ac.uk.

Acknowledgements. This work was supported by the Slovenian Research Agency (Research Program P1-0175).

\section{REFERENCES}

1. S. Petriček, Polyhedron 23 (2004) 2293-2301.

2. S. Petriček, Z. Anorg. Allg. Chem. 631 (2005) 1947-1952.

3. S. Petriček, Z. Anorg. Allg. Chem. 634 (2008) 377-381.

4. S. Petriček and N. Senčar, Z. Anorg. Allg. Chem. 634 (2008) 1619-1625.

5. S. Petriček, Acta Chim. Slov. 56 (2009) 426-433.

6. U. Baisch, D. B. Dell'Amico, F. Calderazzo, R. Conti, L. Labella, F. Marchetti, and E. A. Quadrelli, Inorg. Chim. Acta 357 (2004) 1538-1548.

7. G. B. Deacon, T. Feng, P. C. Junk, G. Meyer, N. M. Scott, B. W. Skelton, and A. H. White, Aust. J. Chem. 53 (2000) 853-865.

8. G. B. Deacon, D. J. Evans, and P. C. Junk, Z. Anorg. Allg. Chem. 628 (2002) 2033-2036.

9. S. Anfang, M. Karl, N. Faza, W. Massa, J. Magull, and K. Dehnicke, Z. Anorg. Allg. Chem. 623 (1997) 1425-1432.

10. V. Ripert, L. G. Hubert-Pfalzgraf, and J. Vaissermann, Polyhedron 18 (1999) 1845-1851.

11. M. G. B. Drew and J. A. Hutton, J. Chem. Soc., Dalton Trans. (1978) 1176-1179.
12. A. S. Batsanov, J. A. K. Howard, A. K. Hughes, and A. J. Kingsley, Acta Crystallogr. Sect. C: Cryst. Struct. Commun. 55 (1999) IUC9900137.

13. A. Malassa, H. Görls, A. Buchholz, W. Plass, and M. Westerhausen, Z. Anorg. Allg. Chem. 632 (2006) 2355-2362.

14. S. Petriček and A. Demšar, Polyhedron 29 (2010) 3329-3334.

15. N. N. Greenwood and A. Earnshaw, Chemistry of the Elements, $2^{\text {nd }}$ ed., Butterworth-Heinemann, Oxford, (1997), p. 1131.

16. R. D. Shannon, Acta Crystallog. A 32 (1976) 751-767.

17. C. A. Kosky, J. P. Gayda, J. F. Gibson, S. F. Jones, and D. J. Williams, Inorg. Chem. 21 (1982) 3173-3179.

18. S. A. Cotton, V. Franckevicius, and J. Fawcet, Transition Met. Chem. 27 (2002) 38-41.

19. S. Jin, M. Nieuwenhuyzen, W. T. Robinson, and C. J. Wilkins, Acta Crystallogr., Sect. C: Cryst. Struct. Commun. 48 (1992) 274-279.

20. V. Kubicek, P. Vojtisek, J. Rudovsky, P. Hermann, and I. Lukes, Dalton Trans. (2003) 3927-3938.

21. O. Schneider, E. Gerstner, F. Weller, and K. Dehnicke, Z. Anorg. Allg. Chem. 625 (1999) 1101-1106.

22. R. L. Dutta and A. Syamal, Elements of Magnetochemistry, second ed., Affiliated East - West PVT LTD, New Delhi, 1993.

23. Z. Otwinowski and W. Minor, Methods Enzymol. 276 (1997) 307-326.

24. G. M. Sheldrick, SHELXS-97, A Program for Automatic Solution of Crystal Structures, University of Göttingen, Göttingen, Germany, 1997.

25. G. M. Sheldrick, SHELXL-97, A Program for Crystal Structure Refinement, University of Göttingen, Göttingen, Germany, 1997.

26. K. Brandenburg, DIAMOND, Crystal Impact, GbR, Bonn, Germany, 1999.

27. L. J. Farrugia, J. Appl. Crystallogr. 30 (1997) 565.

28. A reaction of $\mathrm{CoCl}_{2} \cdot 6 \mathrm{H}_{2} \mathrm{O}$ and dme in presence of excess amount of $\left(\mathrm{CH}_{3}\right)_{3} \mathrm{SiCl}$ afforded the complex 1 by stirring of the mixture for two days at room temperature.

29. S. Htoon and M. F. C. Ladd, J. Cryst. Mol. Struct. 3 (1973) 95-102.

30. P. Sobota, J. Utko, S. Szafert, Z. Janas, and T. Glowiak, J. Chem. Soc., Dalton Trans. (1996) 3469-3473.

31. U. Englert, Coord. Chem. Rev. 254 (2010) 537-554.

32. J. C. Hierso, D. D. Ellis, A. L. Spek, E. Bouwman, and J. Reedijk, Chem. Comm. (2000) 1359-1360.

33. B. M. Antti, Acta Chem. Scand. A 29, (1975) 76-88.

34. T. Dudev and C. Lim, J. Am. Chem. Soc. 122 (2000) 1114611153. 